\title{
Avaliação da redução de Enterococcus faecalis no canal radicular e nos túbulos dentinários utilizando diferentes substâncias químicas auxiliares e técnicas de irrigação: estudo in vitro.
}

\author{
Ana Beatriz Safady Lopes*, Augusto Rodrigues Lima, Priscila Amanda Francisco, Daniel Rodrigo Herrera, Maria \\ Cristina C Carvalho, Gabriel Abuna, Mario A C Sinhoreti, Brenda P F A Gomes
}

\section{Resumo}

A terapia endodôntica tem como objetivo a eliminação da infecção do sistema de canais radiculares. $O$ preparo mecânico dos instrumentos endodônticos é incapaz de promover completa desinfecção de algumas áreas devido às complexidades anatômicas, sendo assim é necessário a utilização de substâncias químicas auxiliares (SQA). Este estudo teve como objetivo avaliar a eficácia, in vitro, da irrigação convencional (IC) e da irrigação com agitação ultrassônica (AUS) de substâncias químicas auxiliares [clorexidina ( $\mathrm{CHX)} 2 \%$, hipoclorito de sódio ( $\mathrm{NaOCl}$ ) $2,5 \%$ ] nas apresentações em solução e gel, na redução de E. faecalis no canal radicular (CR) e nos túbulos dentinários (TD). Solução salina e gel de natrosol 1\% foram utilizados como substâncias inertes controles. Foram selecionadas 120 raízes de pré-molares inferiores, que foram padronizadas em $15 \mathrm{~mm}$ e posteriomente contaminadas com ciclos de centrifugação alternados e troca do meio de cultura a cada dois dias, por 10 dias com E. faecalis. Em seguida, foram divididos os dentes em 12 grupos $(n=10)$ de acordo com a técnica de irrigação e dos irrigantes utilizados. Amostras bacteriológicas do CR foram coletadas antes e imediatamente após o uso das SQA e seus neutralizadores [tween 80 a $0,5 \%$ + lecitina de soja a $0,07 \%(\mathrm{CHX})$; tiosulfato de sodio a $5 \%(\mathrm{NaOCl})]$, as quais foram cultivadas para obter a contagem das unidades formadoras de colônia (UFC). Após os protocolos de irrigação, 3 especimes de $1 \mathrm{~mm}$ de dentina radicular referentes aos 3 terços radiculares (cervical, médio e apical) foram obtidos, os quais foram analisados através de Microscopia Confocal de Varredura a Laser (MCVL) para identificar celulas bacterianas viáveis (CV) dentro dos TD. Não houve diferença significativa entre $\mathrm{NaOCl}$ e $\mathrm{CHX}$ nas diferentes apresentações, sendo mais efetivas que as substâncias controles tanto na contagem de UFC como na analise de MCVL $(p<0,05)$ na AUS. A irrigação com a AUS foi mais efetiva que a IC em todas as substâncias utilizadas. Conclui-se que a irrigação com AUS é capaz de promover uma maior desinfecção que a IC, tanto no CR como nos TD, independente da forma de apresentação.

\section{Palavras-chave:}

Endodontia, Microbiologia, Solução Química Auxiliar

\section{Introdução}

O desenvolvimento de tecnologias que otimizem o preparo químico-mecânico deve ser encorajado para definição de protocolos endodônticos dinâmicos e mais eficientes. A ativação ultrassônica das substâncias químicas auxiliares é uma alternativa promissora na complementação da desinfecção dos canais radiculares, uma vez que esta é uma etapa essencial para o sucesso da terapia endodôntica. Desta forma, este estudo visa avaliar a eficácia de diferentes técnicas de irrigação utilizando de diferentes substâncias na redução de $E$. faecalis utilizando contagem de UFC e a MCVL.

\section{Resultados e Discussão}

Figura 01. Contaminação dos túbulos dentinários com E. faecalis. $A$ - Microscopia Eletrônica de Varredura (MEV); B- MCVL.

- O estudo piloto mostrou que o protocolo de contaminação da luz dos canais e do interior dos túbulos dentinários foi eficiente como ilustrado pela MCVL e MEV.
- A contagem de UFC mostrou que AUS é mais efetivo que IC. As substancias químicas ativas $(\mathrm{CHX}$ e $\mathrm{NaOCl}$ ) foram capazes de promover maiores reduções de UFC quando comparadas com as soluções intertes controles $(p<0,05)$.

- Os resultados do MCVL mostraram que IC deixou muitas (CV) nos túbulos dentinários (média de $74 \%$ CV), AUS apresentou melhores resultados (média $36 \% \mathrm{CV}$ ) do que IC em todos os terços radiculares.

- Não houve diferença significativa entre $\mathrm{NaOCl}$ e $\mathrm{CHX}$, que apresentaram maiores capacidades de redução que as soluções controles tanto na contagem de UFC como na analise de MCVL $(p<0,05)$.

\section{Conclusões}

Concluiu-se que a irrigação com AUS é capaz de promover uma maior desinfecção que a IC, tanto nos CR como nos TD, independente da forma de apresentação.

\section{Agradecimentos}

FAPESP 2015/23479-5; CNPq 308162/2014-5; PIBIC 100453/2018-0; PIBIC 102276/2019-6 \& CAPES (código 001) 